UDK: 821.134.2-31.09 Галдос Б. П.

$81 ' 255.4$

811.134.2+821.134.2(497.11)

DOI: https://doi.org/10.18485/legado_hispanico.2020.ch3

\author{
Владимир Карановић ${ }^{\mathbf{1}}$ \\ Универзитет у Београду \\ Србија
}

\title{
РЕЦЕПЦИЈА СТВАРАЛАШТВА БЕНИТА ПЕРЕС ГАЛДОСА У СРПСКОЈ КУЛТУРНОЈ И АКАДЕМСКОЈ СРЕДИНИ
}

\begin{abstract}
Резиме
Рецепција и присуство шпанске књижевности на Балканском полуострву, а посебно у Србији, у протеклим деценијама били су предмет интересовања и истраживања наших угледних хиспаниста, који су се бавили њеном преводном, књижевноисторијском, критичком, уметничком и културном рецепцијом. Прве трагове присуства и рецепције стваралаштва Бенита Перес Галдоса везујемо за средину XX века, када је на хрватскосрпски преведен роман Доња Перфекта, док тек од прве деценије XXI века можемо говорити о систематској преводилачкој активности и о периоду темељније преводне, критичке, књижевноисторијске или академске рецепције стваралаштва овог значајног шпанског приповедача.

Циљ овог чланка је да се представи корпус дела Бенита Перес Галдоса преведен на српски језик (од средине XX века до данас) и анализира њихова рецепција кроз преводилачко и читалачко искуство преводилаца и хиспаниста у нашој средини. Осим превода, предмет истраживања су и књижевнокритички, књижевноисторијски, научни и стручни текстови посвећени различитим видовима стваралаштва Перес Галдоса

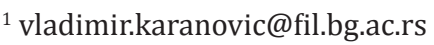


(предговори, поговори, поглавља у монографским публикацијама, научни чланци објављени у тематским зборницима и часописима, мастер радови одбрањени на српским универзитетима).

Преводна, књижевноисторијска и критичка рецепција дела Перес Галдоса нереткоје била резултатличне иницијативе, упрви махобразованих културних посленика ширег спектра интересовања и образовања, који су били заинтересовани за хиспанске теме, а потом и школованих хиспаниста и преводилаца, пре свега на српском културном простору, који су понудили превод најважнијих дела овог писца и прегршт пропратних критичких текстова који су могли утицати на хоризонт очекивања домаћег читаоца. Књижевнокритичка и књижевноисторијска активност јављају се некад паралелно, а често након објављивања превода дела, као одјек и последица критичког и теоријског уопштавања за које су потребни време и предан стручни и научни рад. Осим информативне функције, текстови наших хиспаниста сведоче о високом степену свести о значају реализованог подухвата у дијалогу међу удаљеним културама.

Кључне речи: рецепција шпанске књижевности, Бенито Перес Галдос, шпанска књижевност реализма, књижевно превођење, хиспанистика у Србији.

\section{1. Увод}

Превођење одређеног (књижевног) текста одавно није само процес који се одвија међу језицима, већ сложена радња која подразумева комуникацију међу културама. Овако схваћен процес превођења имао је значајну улогу у друштвено-културним променама у свим развијенијим културама (Манчић 2010: 48-49). Предуслов сваке књижевне рецепције несумњиво је постојање превода одређеног дела на језику културе чијој преводној књижевности ће припадати. Преводилац кроз своју стваралачку активност и делатност у значајној мери конкретизује одређено књижевно дело и представља важан зупчаник у механизму рецепције у страној и новој културној средини (Буњак 1998: 18-19). Превод је чињеница која се мора узети у обзир када се говори о рецепцији одређеног страног дела у другој националној и културној средини. У процесу конкретизације дела преводилац тако постаје први читалац, први тумач дела страног писца, први његов интерпретатор и оцењивач. По речима Петра Буњка (1998: 20),

већ сам избор дела за превођење, па онда процес превођења и најзад публиковање превода - дакле, и пре но што превод неког дела доспе 
у руке страног читаоца - носе извесна обележја рецепције, иако је, наравно, реч о појединачној или у крајњем случају ограниченој појави.

Однос преводне и националне књижевности умногоме је сложен и занимљив при истраживањима питања рецепције књижевности, а постоји неколико важних питања на које се мора јасно одговорити уколико тежимо објашњењу улоге преводне књижевности у локалном културном контексту: 1) шта се преводи?; 2) зашто се преводи?; 3) како се преводи?; и 4) како преводи делују? (Јанићијевић 1977: 40). Дакле, уколико настојимо да у потпуности изучимо одређени предмет рецепције, неопходно је одредити све услове у којима се она одвија. У том смислу проучавају се 1) средина, њен општи систем вредности, установе, одлике књижевног живота и традиције, културноисторијске чињенице у којима се рецепција одвија; 2) околности под којима страно дело улази у оптицај и тако се конкретизује (личност преводиоца, критеријуми за избор дела, процес настанка превода, околности публиковања, итд.); 3) анализа конкретног превода (у односу на оригинал, на друга преведена дела, на књижевну традицију и актуелну књижевну норму изворне књижевности); 4) непосредни одјек дела код „образованих читалаца“ (критика, анализа, оцене, вредновање струке); 5) одјек превода у ширим круговима публике и културне јавности; 6) пројекција преводног дела на норму и стандарде књижевности-примаоца; 7) место преводног дела у књижевној традицији нове средине; и 8) питање примене искуства стеченог лектиром реципираног дела неке стране књижевности у оригиналном књижевном процесу (Буњак 1998: 23-24).

Први сусрети српске и шпанске културе у смислу превођења и рецепције књижевних дела са шпанског језика, јављају се током друге половине XIX века, и односе се на шпанске књижевне класике као предмет рецепције. У прво време, често се бележе и случајеви посредног присуства дела шпанске књижевности, преведених са француских изворника. Тек ће у првим деценијама XX века (посебно током тридесетих година и актуелности Шпанског грађанског рата у југословенској јавности) шпанска књижевност у значајнијој мери бити присутна на заједничком, тада југословенском простору, пре свега кроз преводе дела Федерика Гарсија Лорке и Висентеа Бласко Ибањеса, несумњиво због тадашње популарности њиховог књижевног опуса и повољне идеолошке климе која је владала у 
оновременим издавачким круговима. Међутим, интересовање наше културне средине за превођење дела других шпанских књижевника, иако интензивније у каснијим деценијама XX века, биће резултат личне иницијативе преводилаца, професора, културних посленика, а мање јасне културне политике или потребе да се две географски удаљене културе повезују кроз унакрсно преношење књижевних дела до оне друге културе.

С друге стране, када говоримо о академској средини, систематско проучавање шпанског језика и књижевности започиње 1971. године, оснивањем Групе за шпански језик и књижевност на Филолошком факултету Универзитета у Београду (Солдатић 2010: 22). Током седамдесетих година XX века, када је српска хиспанистика коначно изнедрила и прве хиспанисте и преводиоце, настају услови за озбиљнију преводилачку, академску, научну рецепцију дела шпанских и хиспаноамеричких књижевника. Тако већ од осамдесетих година XX века до данас настају бројне научне и стручне публикације посвећене различитим периодима шпанске и хиспаноамеричке књижевности. ${ }^{2}$ Интерпретативна рецепција шпанске (али и хиспаноамеричке) књижевности има све већи значај у савремено доба, посебно у протеклим деценијама развоја српске хиспанистике, као јасан резултат постојања академског и институционализованог интересовања српских хиспаниста за разне видове хиспанског књижевног корпуса (Дицков 2014: 102).

Предмет анализе у овом раду биће рецепција стваралаштва Бенита Перес Галдоса (1843-1920) кроз преводе на српски и српскохрватски/хрватскосрпски језик (будући да је некад постојао јединствен културни и читалачки југословенски простор, а да није било потребно да се превод објављен у једној републици појављује у посебном издању на различитим језичким варијантама), кроз пропратне критичке текстове (предговоре и поговоре преводима), научне чланке, поглавља у монографским публикацијама, али и мастер радове у академској средини.

\section{2. Књижевни опус Бенита Перес Галдоса у српским преводима}

Аутори шпанског књижевног реализма, с изузетком Висентеа Бласко Ибањеса, чија дела се први пут на хрватскосрпски/

\footnotetext{
${ }^{2}$ Vid. Dickov 2014: Vesna Dickov. «Las literaturas hispánicas y el pensamiento crítico y teórico serbio», Colindancias, 5: 75-102. [https://colindancias.uvt.ro/index.php/ colindancias/article/view/41] Web. 15/11/2019.
} 
српскохрватски језик преводе од двадесетих година XX века, тек у новије време у већем обиму присутни су у српској преводној књижевности. Могући разлог за овакво стање је непостојање конзистентнијих међукултурних веза Шпаније и Србије/Југославије, али и слабо интересовање (недовољно обавештене) српске културне средине, која је услед друштвено-историјских околности и културних веза традиционално била наклоњена другим европским културним и уметничким срединама (француској, енглеској, америчкој, немачкој, италијанској, руској, итд.). Тако нпр. дела Перес Галдоса нису обухваћена првим антологијама приповедака које су настајале на југословенском тлу средином XX века ${ }^{3}$ нити у каснијим изборима српских романиста ${ }^{4}$.

Први податак о превођењу неког дела Перес Галдоса код нас појављује се средином XX века. Реч је о првом интегралном преводу романа Доња Перфека (Doña Perfecta), објављеном у „Државном издавачком подузећу Хрватске“ у Загребу 1952. године, у хрватскосрпској варијанти језика. Преводилац је Иван Вечерина, чија је преводилачка активност са шпанског језика била изражена током 50-их и 60-их година XX века. ${ }^{5}$ Посреди је коректан превод у којем је одговорност „првог читаоца“ у првом плану, будући да локална читалачка средина још увек нема директне увиде у стваралаштво овог шпанског књижевника. Издање садржи и пропратни текст под насловом „Напомена о писцу“ (рp. 241-244), у којем ауторка Милена Вечерина први пут на нашим просторима доноси читаоцима на само неколико страница један синтетички, информативни текст о животу Бенита Перес Галдоса, његовом образовању, првим списатељским корацима, основним одликама стваралаштва, а посебно наглашавајући укупну оцену значаја романескног корпуса у контексту шпанске књижевности епохе и свеукупне европске књижевности реализма. Ауторка у последњим фрагментима текста кратко анализира преведено дело, ликове,

\footnotetext{
${ }^{3}$ Španjolske pripovijetke, preveo sa španjolskoga Josip Tabak, Zagreb / Beograd: Novo pokoljenje, Biblioteka izabranih pripovijetki, Kolo V, Svezak 4, 1949.

${ }^{4}$ Antologija španske pripovetke od Servantesa do danas, izabrao i priredio Radivoje Konstantinović, preveli Radivoje Konstantinović i Duško Vrtunski, Novi Sad: BratstvoJedinstvo, 1984.

${ }^{5}$ Иван Вечерина је са шпанског језика, осим романа Доња Перфекта Бенита Перес Галдоса, превео и дела других шпанских и хиспаноамеричких писаца: Вртлог (1954) Хосеа Еустасија Рибере, Зли духови (1957) Хорхеа Икасе и Тророги шешир (1960) Педра Антонија де Аларкона.
} 
садржину, идеје, закључујући да је реч о најпознатијем делу Перес Галдоса изван граница Шпаније, те да је то ретко његово дело које је већ преведено на многе европске језике (француски, енглески, немачки, португалски, шведски), а сад и на хрватскосрпски.

Након овог првог превода на хрватскосрпски, нема података о преводној рецепцији дела Бенита Перес Галдоса до времена културне и политичке дезинтеграције јединственог југословенског простора почетком 90-их година XX века. У наредним деценијама, озбиљније интересовање за стваралаштво овог плодног шпанског реалисте биће резултат интересовања и активности српских хиспаниста, које је формирала и усмеравала хиспанистичка и академска средина. Нови миленијум створиће и нове услове у области издаваштва у Србији. Након деценије изолације, санкција и изостанка озбиљнијег бављења издавачким и преводилачким подухватима у области шпанске и хиспаноамеричке књижевности, значајну улогу имаће финансијска помоћ и пројектно финансирање које је покренуло Министарство културе и спорта Краљевине Шпаније у области превођења дела са шпанског на друге језике широм света. Српски преводиоци и хиспанисти су ову прилику искористили да нашим читаоцима на матерњем језику кроз превод приближе бројне класике пре свега шпанске књижевности, приљежно радећи на објављивању критичких издања и додатног апарата који би олакшао читање, тумачење и критичко вредновање дела. Део овог пројектног финансирања била су и готово сва преведена дела Бенита Перес Галдоса у Србији, од 2006. до дана данашњег, уз изузетак нпр. превода романа Разбаштињена (2012), који је у потпуности финансијски подржала издавачка кућа Пи-Прес из Пирота. Значајну подршку дали су и Амбасада Краљевине Шпаније у Београду и Институт Сервантес, који је стваралаштву овог писца или едицијама превода у којима се налазе његова дела, посветио бројне културне догађаје и књижевне вечери.

Први савременији превод дела Перес Галдоса код нас је роман Назарен (Nazarín), објављен 2006. године у Издавачком предузећу „Рад“. Дело је превела Александра Манчић, један од најплоднијих преводилаца у нашој хиспанистичкој средини, ауторка неколико монографских публикација, носилац награда за превођење и есејистику. Осим о несумњивој тачности овог превода, може се говорити и о јасном и очигледном таленту преводиоца да на српски језик пренесесвезначењскенијансе оригиналногтекста, специфичан стил и језик епохе уз оригиналну пересгалдосовску лексику, али и 
учестале асоцијације и алузије интелектуалног предзнака, којима је шпански писац посебно био склон у позној фази романескног опуса. У поговору под насловом „О писцу и делу“ (Манчић 2006: 217-219), ауторка српском читаоцу нуди основне податке о животу Перес Галдоса, његовом образовању, интелектуалном развоју и професионалном животу у шпанској престоници. Посебну пажњу посвећује преведеном делу, роману Назарен, који припада познијој фази романескног стваралаштва шпанског реалисте и натуралисте, сврставајући га у групу дела која припадају „духовном реализму / натурализму“, карактеристичном за последње године XIX и почетак $\mathrm{XX}$ века. У сегменту у којем наводи одлике лика протагонисте, Манчић настоји да читаоца подстакне на темељније разматрање и активно читање дела, те тумачење његове суштине и то кроз метод проблематизације важних питања романа, природе протагонисте и његове симболичке функције.

Већ наредне године (2007) у истој издавачкој кући Александра Манчић објављује превод романа Тристана (Tristana), још једно Перес Галдосово дело из позне фазе стваралаштва, када натуралистичке тенденције у књижевности уступају место приступу у којем се наглашавају унутрашњи светови ликова, психолошке одлике, анализа духовности и интелектуализација многих важних питања не само оновременог већ и духа данашњице. Преводитељка је очигледно била свесна значаја превођења овог романа, који сада и на српском језику омогућава да локална читалачка средина спозна специфичан интелектуални хоризонт Бенита Перес Галдоса у делу о жени епохе и тзв. „женском питању“. Будући да Тристана у одређеној мери спада у роман с тезом, преводилац је доследан у решењима које проналази како би идеолошка порука била јаснија, а динамика оригиналног шпанског текста нетакнута. У додатном тексту - „Галдос у Буњуеловој библиотеци“ (2007: 197-202) ауторка се бави пре свега значајем који Буњуелова екранизација (1970) Перес Галдосовог романа има у развоју рецепције дела. Осим локализације романа у стваралаштву аутора, његове књижевничке и интелектуалне активности у времену настанка дела, размотрена су и питања борбе за женска права, теза о роману као манифесту феминизма или пак угњетавања оновремене жене у ригидном друштвеном систему, као и низ аутобиографских елемената или личних интелектуалних пројекција које се у делу могу открити. У већ традиционалном маниру проблематизовања основних питања књижевног дела, Александра Манчић текст завршава анализом 
сличности и разлика у изражајним средствима оригиналног шпанског романа и његове филмске адаптације и интерпретације.

Догађај од изузетног значаја у историји рецепције шпанске књижевности реализма без сумње је објављивање новог превода романа Доња Перфекта (Doña Perfecta) 2007. године, у издавачкој кући „Клио“ из Београда. Овај класик Перес Галдосовог прозног опуса најучесталије је превођено дело у процесу интеркултурног посредовања у хиспанистичким круговима и бројним европским преводним књижевностима. Чини се да заокупља пажњу преводилаца и хиспаниста-истраживача широм света пре свега због универзалних вредности, актуелних и применљивих у различитим срединама, културним и друштвеним амбијентима, али и присутних на општем, симболичком нивоу у разним фазама развоја друштва, од настанка романа до дана данашњег. Преводитељка Биљана Буквић (Исаиловић) не само да је успела да на српски језик пренесе све значајне елементе пересгалдосовског израза, језика и стила, већ је умешним преводилачким решењима допринела ваљанијем разумевању амбијента романа, психологије ликова и сложених романескних ситуација. Квалитет овог преводилачког подухвата препознао је и жири за доделу преводилачке награде „Радоје Татић“ 2008. године, те је управо овај превод прогласио најбољим остварењем. У образложењу одлуке (Фонд „Радоје Татић“ 2008) жири указује на све квалитете превода и значај конкретног дела у новој културној средини:

Галдосов језик је раскошан, течан, ритам казивања жив, пун акције - што наравно, све доживљавамо кроз изванредан превод Биљане Исаиловић Буквић. У роману има и доста народних изрека и пословица, за шта наш преводилац налази адекватне саобразности у српском. И у сликању атмосфере дела и у одговарајућој лексици које су својствене крају 19. и почетку 20. века, наш преводилац вешто и са умећем креативног превођења налази одговарајућа језичка решења у српском језику. Тако долазимо до превода који се чита као да је дело писано на српском, што је највећи домет сваког успешног преводиоца и уједно његова највећа амбиција. Захваљујући двоструком постигнућу, написаног и преведоног, роман Доња Перфекта је дело које се чита у даху.

Наведеном образложењу комисије требало би додати и оцену да овај превод носи снажан ауторски печат преводиоца,

\footnotetext{
${ }^{6}$ [http://www.forata.org/sr/fond/nagrada/119/Obrazlo\%C5\%BEenje-\%C5\%BEirija-2008.htm]
} 
који јасно препознајемо у спартанској борби с компликованим деоницама текста, али и у смелом и оригиналном преводилачком изразу Биљане Буквић. Пример који илуструје ову тврдњу је нпр. задржавање оригиналне шпанске графеме $\tilde{n}$ у наслову дела уместо транскрибованог облика речи - доња. Издање превода није објављено уз додатни текст преводиоца или неког другог хиспанисте, у којем би се српски читалац упознао с основним биографским подацима писца или с књижевноисторијским контекстом настанка и рецепције дела.

Једини до сада на српски преведени роман Бенита Перес Галдоса из корпуса историјских романа, познатих под заједничким називом „Епизоде националне историје“7 (Episodios nacionales) јесте Tрафалгар (Trafalgar), објављен 2008. године у издавачкој кући „Утопија“ из Београда. Преводилац је Владимир Нинковић, тада млади хиспаниста чија је намера очигледно била да понуди српским читаоцима и дело из надасве оригиналног и јединственог корпуса романа у историји шпанског реализма. Трафалгар је не само први наслов из прве серије, већ и најпознатије дело из ове групе Перес Галдосових романа, познато и изван граница Шпаније. Превод је сачињен у духу епохе, уз пажљив одабир лексике, поштовање језичких и стилских одлика оригинала, често проблематичног и у многим видовима подложног преводилачком и читалачком тумачењу, што процесу превођења романа овог шпанског реалисте увек даје дозу посебног искуства и књижевног доживљаја. С обзиром на то да је дело недвосмислено историјског карактера, те да описане историјске личности или историјске алузије у шпанском националном контексту махом нису познате публици и читаоцима који дело прихватају у српској културној средини, изненађује одсуство додатних референци, објашњења или преводилачких коментара у тексту превода. Пропратни текст у виду поговора под насловом „Белешка о писцу“ (2008: 157-158) представља сјајан пример добре традиције по којој читаоца у оквирима локалне преводне књижевности концизно, јегровито и ненаметљиво треба упознати с најважнијим видовима стваралаштва писца и контекстом настанка дела. Тако Нинковић представља биографске околности писца, смештајући га у тзв. „Генерацију 1868.“, уз друге великане шпанске писане речи друге половине века. Кратко разматра романескну поетику писца, карактеристичну за доба реализма, уз

\footnotetext{
7 Укупно 46 романа распоређених у пет серија по десет дела, премда је последња серија остала недовршена.
} 
све специфичности које шпанска културна и књижевна средина подразумевају. Посебну пажњу аутор текста усмерава ка анализи књижевних узора Бенита Перес Галдоса (Балзаку и Дикенсу) и шпанској књижевној традицији која је обликовала не само књижевно дело већ и теоријску мисао шпанског реалисте. Последњи фрагмент текста посвећен је кратком представљању преведеног романа, контексту објављивања, развоју рецепције, значају у стваралаштву писца, а индикативна је и општа оцена дела у контексту, пре свега националне културе, али и у процесу интеркултурне размене.

Након ове прве фазе превођења Перес Галдосових романа у српској културној средини, преводилачка активност наших хиспаниста организује се кроз посебне тематске едиције дела, које обухватају неке од најважнијих и најпознатијих наслова историје шпанског књижевног реализма и натурализма. Важан догађај у том смислу је и покретање едиције „Класици шпанског реализма“ у издавачкој кући Пи-Прес из Пирота, у којој је од 2010. до 2012. године објављено укупно осам дела одабраних реалиста - Емилије Пардо Басан, Хуана Валере, Хосеа Марије де Переде, Леополда Алас Кларина и Бенита Перес Галдоса. У оквиру овог пројекта Далибор Солдатић, хиспаниста, универзитетски професор, дипломата и преводилац, објавио је 2012. године превод романа Разбаштињена (La desheredada). Избор овог важног дела шпанске књижевности, уједно првог романа шпанског натурализма, резултат је сарадње и приближавања естетичких и књижевноисторијских критеријума преводиоца и уредника едиције (Владимира Карановића). Преводилац је имао сложен и захтеван задатак, који је подразумевао не само сусрет са специфичном поетиком књижевног текста писца, већ и с низом језичких особености, типичних за мадридски жаргон, лексичке локализме и регионализме, који захтевају будност преводиоца, искуство у превођењу и способност проналажења најбољих еквивалената у српском језику, а неретко и формирање неологизама јер се у одређеним случајевима решења у семантичком или контекстуалном смислу могу сматрати непримереним или недовољно поузданим. О томе јасну идеју има и преводилац, те се у поговору под насловом „Бенито Перес Галдос и шпански роман“ (Солдатић 2012: 509-510) осврће на проблем превођења Перес Галдосових романа:

Једна од највећих вредности ове прозе проистиче из умећа аутора да унесе колоквијални говор у роман и тако створи једну интимну 
атмосферу. [...] Та чињеница у приличној мери отежава посао преводиоца јер нису малобројни случајеви када се значење појединих речи или читавих израза не може наћи у стандардним речима, па чак ни у специјализованим речницима као што је Diccionario de argot español, Виктора Леона. Ту и тамо захваљујући Интернету и Word reference Forumu дошли смо до решења. На појединим местима драгоцена нам је била студија Прилози проучавању колоквијалног језика Галдоса (Manuel C. Lassaletta. Aportaciones al estudio del lenguaje coloquial galdosiano, Ínsula. Madrid. 1974. 293 str.). С друге стране, треба имати у виду да је у питању шпански језик којим се говори у XIX веку. У преводу на српски покушали смо да ту нијансу постигнемо донекле кроз синтетичку структуру и ред речи у реченици, а да опет не добијемо текст који је тежак за читање. Пошто је у питању проза са доста колоквијалних израза, негде смо били приморани да импровизујемо и да у преводу дајемо решења која више одговарају колоквијалним изразима српског језика. У којој мери су дата решења успешна оцениће читаоци. Надамо се да смо успели да пренесемо на српски аутентичност прозе Перес Галдоса.

Аутор поговора поступно, синтетички и умешно упознаје српског читаоца с фактографијом живота писца, одликама стваралаштва и специфичаним контекстом настанка преведеног романа. Посебну пажњу Солдатић посвећује истицању идеолошког капацитета Перес Галдосових романа, амбијенту и простору у којем се одвија већина дела, шпанској престоници - Мадриду -, социјалном раслојавању становника, приказу различитих урбаних целина, те граду који постаје важан колективни лик у значајном де́лу романескног корпуса. За разлику од досадашњих пропратних текстова преводилаца, у овом несумњиво препознајемо и намеру да се шири круг читалаца обавести о конкретним и бројнијим видовима и проблемским блоковима дела. Стога Солдатић анализира и преведени роман у кључу натуралистичке поетике, романескне естетике аутора, симболичког алегоријског нивоа протагонисткиње Исидоре Руфете као представнице друштвеног слоја у задатим историјским околностима. На крају, од изузетне је важности и Солдатићева позитивна оцена целокупног стваралаштва Бенита Перес Галдоса, чија је перцепција у Шпанији била променљива током историје шпанске књижевности, премда у новије време добија заслужено место у свим релевантним прегледима шпанске књижевности реализма.

Током 2014. године Драгана Бајић, хиспаниста и преводилац, у сарадњи са Слободанком Стојановић и Иваном Катић, приредила је 
двојезичну, шпанско-српску антологију под насловом Шианска прича на прелазу из XIX у XX век / El relato español en la transición del siglo XIX $a l X X$, чији су покровитељи Амбасада Краљевине Шпаније у Београду, Институт Сервантес и Удружење књижевних преводилаца Србије. Овом антологијом обухваћене су кратке приче 11 аутора, углавном припадника шпанског романтизма и постромантизма (Маријано Хосе де Лара, Густаво Адолфо Бекер), реализма и натурализма (Хуан Валера, Педро Антонио де Аларкон, Емилија Пардо Басан, Леополдо Алас Кларин, Армандо Паласио Валдес, Висенте Бласко Ибањес), али и модернизма (Рамон Марија дел Ваље-Инклан) и Генерације 98. (Мигел де Унамуно). Свакој причи претходи страница посвећена основним биографским подацима аутора и најважнијим смерницама стваралаштва. У уводном тексту под насловом „Кратка уводна реч за кратку антологију“ Драгана Бајић (2014: 9-11) објашњава околности настанка овог занимљивог избора кратких прича. Посреди је преводилачки пројекат ученика Филолошке гимназије у Београду под рецензентским радом професорки Драгане Бајић и Слободанке Стојановић, а циљ је био да млади талентовани филолози спознају основе преводилачке активности и подаре српским читаоцима избор краћих прозних форми наведеног периода шпанске књижевности. Своје место у антологији морао је имати и Бенито Перес Галдос, који је осим великог броја романа, аутор и краћих прозних форми, веома популарних у оновременој Шпанији. Приповетку „Донжуан“ («El Don Juan»), која припада првим годинама Перес Галдосове књижевничке активности (1868), превела је Сара Јокић, а јасна реченица, мелодичност, језичка патина, те свеукупна уочљива саобразност текста и примереност српском језичком изразу, сведоче о квалитетном подухвату и плодном сусрету преводиоца и редактора превода с одабраним миникорпусом пересгалдосовске приповетке.

Почев од 2013. године издавачка кућа „Партенон“ из Београда покренула је серију превода са шпанског језика под називом «Bibliotheca Hispania»" ${ }^{8}$ чији су актуелни уредници хиспанисти и преводиоци Жељко Донић, Изабела Бељић и Снежана Јовановић. До краја 2019. године објављено је укупно 20 наслова, подељених у два кола, а међу њима су и два романа Бенита Перес Галдоса: Фортуната и Хасинта и Златна фонтана.

\footnotetext{
${ }^{8}$ Vid. Donić 2017: Željko Donić, «La colección Bibliotheca Hispania en la casa editorial Partenon: primera colección de clásicos hispánicos», Beoiberística, revista de estudios ibéricos, latinoamericanos y comparativos, I/1: 205-210. [http://beoiberistica.fil.bg.ac.rs/ index.php/beoiberistica/article/view/16/16] Web. 15/02/2020.
} 
Превод романа Фортуната и Хасинта - Две приче о удатим женама (Fortunata y Jacinta - Dos historias de casadas) објављен је у два тома 2015. године у првом колу наведене едиције, а преводилац дела - Далибор Солдатић - након превода романа Разбаштињена, враћа се стваралаштву и превођењу дела чувеног шпанског реалисте и натуралисте, премда због избора дела сада уз далеко озбиљнији преводилачки задатак и већу одговорност према локалној културној средини и преводној књижевности. Овај роман припада најплоднијој фази романескне активности Перес Галдоса, а сврстава се у саме врхове шпанске прозе свих времена и сматра неизоставном лектиром на различитим нивоима у шпанском образовном систему.

Поговор Далибора Солдатића, иако под општим, раније познатим насловом „Бенито Перес Галдос и шпански роман“ (2015: 517-521), представља у одређеним, пре свега уводним деловима, скраћену и измењену верзију текста објављеног уз превод дела Разбаштињена (2012). Осим познатих података о животу и делу шпанског писца, Солдатић конкретизује и детаљно објашњава разне видове романа: контекст настанка дела, анализира ликове Фортунате и Хасинте, али и друге ликове који су у функцији развоја радње или пак развоја носећег лика. Од значаја су и ауторова наратолошка и стилска анализа романа, с обзиром на степен оригиналности који на тим пољима показује Перес Галдос, а што итекако утиче на процес превођења једног књижевног дела и на ваљан резултат преводилачког процеса. Посебно место Солдатић посвећује тематској анализи (у први план се истичу теме љубави и морала), анализи симболичких функција догађаја, ликова, историјских подударности и свеукупној слици друштвеног система и живота шпанске престонице. Важан део садржине текста јесу и оцене о квалитету романа и његовом месту у хронолошком следу историје шпанске књижевности, с обзиром на то да сведоче о Далибору Солдатићу као изузетном познаваоцу ширег књижевног и друштвено-историјског контекста стваралаштва Бенита Перес Галдоса, али и преиспитивања и ревалоризације којима су његова дела у новије време подвргнута кроз активности бројних стручњака за ову област у Шпанији и у другим земљама.

Последње до сада објављено интегрално дело Перес Галдоса на српском језику је роман Златна фонтана (La fontana de oro) (2018) у преводу Снежане Јовановић, у издању издавачке куће „Партенон“. Овај први званичан роман шпанског реализма, објављен у Шпанији 
1870. године, преводилац и уредници едиције хиспанских класика учинили су доступним и нашој културној средини, свесни његове важности у историји шпанског реализма, али и релевантности у временима непрестане историјске ревалоризације друштвених феномена који неретко имају универзалну вредност, те могу бити занимљиви и географски удаљеним културама. Сложен шпански књижевни дискурс и бројне историјске алузије преводитељка Снежана Јовановић је савладала у потпуности, изналазећи у свакој ситуацији најбоље или најпримереније решење. Српски читалац у прилици је да се кроз бројна минуциозна објашњења у фуснотама упозна с мање познатим историјским чињеницама и специфичном свакодневицом шпанске престонице током турбулентних политичких времена XIX века. Такође, умешност у проналажењу ваљаних српских еквивалената спорних текстуалних сегмената и способност да се врцави хумор, жаргон или оригинални језички регистар најпримереније приближе српском читаоцу без преводилачких „шумова“ или честе импровизације којој преводиоци неоправдано прибегавају, чине ово дело правим бисером међу преводима дела Бенита Перес Галдоса код нас.

Такође, посреди је темељно приређено критичко издање превода, које осим додатних објашњења и смерница читаоцима у примарном тексту превода, доноси и озбиљну студију о овом делу у виду поговора преводиоца, под насловом „Бенито Перес Галдос и роман шпанског реализма“ (2018а: 341-351). Реч је о синтетичкој студији посвећеној важним биографским видовима писца, његовом животном и професионалном путу и развоју, контексту настанка и зачетка шпанског романа XIX века након дугог периода декаденције и заборава који су му омогућиле класичарске поетике претходних векова. Ауторка текста представља и низ књижевноисторијских чињеница о писцима раног реализма и о костумбризму као конститутивном елементу из којег ће настати шпански роман реализма, а за српског читаоца од изузетне важности је и осврт на компаративни контекст и генезу историјског романа не само у Шпанији, већ и у другим земљама. Поглавље овог пропратног текста посвећено роману Златна фонтана, садржи језгровиту и у већем степену конкретизовану анализу разних видова дела. Представљени су садржина романа, костумбристички капацитет дела, односи међу ликовима, њихови немири, унутрашњи светови, симболичка функција у развоју радње, а српски читалац има прилику и да јасно спозна два основна структурна тока - љубавни и историјски -, 
солидно повезана у јединствену целину. Ипак, историчари шпанске књижевности повремено износе судове да је тада млади писац са Канарских острва још увек био недовољно способан да предност и доминацију препусти озбиљној анализи националне историје путем романескног књижевног дискурса. Ауторка добро оцењује да је Златна фонтана Перес Галдосов роман који је можда и највише неоправдано потцењиван у историји рецепције његовог обимног књижевног опуса, а разлоге оваквом стању треба тражити у сферама изван књижевнокритичког и књижевноисторијског вредновања. Ово дела заправо показује степен зрелости младог писца који ће свој списатељски таленат тек показати током наредних деценија, стварајући нека од највреднијих дела свеколике шпанске прозе.

Најновији податак о присуству дела Бенита Перес Галдоса у српској преводној средини проналазимо у Антологији шпанске приче XX века, коју је приредила Драгана Бајић 2019. године за издавачку кућу „Агора“. Реч је тек о првом тому колективног преводилачког подухвата (чак 10 преводилаца), којим су обухваћене приповетке шпанских књижевника од краја XIX и током прве четири деценије $\mathrm{XX}$ века, а међу којима су и две Перес Галдосове приче - „Слагалица или главолом“ и „Где ми је глава?“ - у преводу Драгане Бајић. Ове две приче представљају само илустрацију приповедачког талента шпанског реалисте, који је с посебном пажњом био посвећен, као и већина својих савременика, краћим прозним облицима, сматравши их полигонима за показивање приповедачког капацитета, али и умешности аутора да створи вредно прозно дело. У „Предговору“ Драгана Бајић (2019: 5-8) представља антологију, осврћући се на историјат превођења приповетке како хиспаноамеричких тако и шпанских аутора на српски језик. Овај избор савремене шпанске приповетке, иако не први сличан подухват код нас, ${ }^{9}$ на добар начин

\footnotetext{
9 У југословенском и српском културном простору и у преводној књижевности прву антологију шпанске приповетке проналазимо у хрватскосрпском издању које је приредио Јосип Табак (Španjolske pripovijetke, preveo sa španjolskoga Josip Tabak, Zagreb / Beograd: Novo pokoljenje, Biblioteka izabranih pripovijetki, Kolo V, Svezak 4, 1949). У српској преводној средини каснијих деценија најважнији допринос у овој области дао је Радивоје Константиновић (Antologija španske pripovetke od Servantesa do danas. Izabrao i pripremio Radivoje Konstantinović. Preveli sa španskog Radivoje Konstantinović i Duško Vrtunski, Novi Sad: Bratstvo-jedinstvo, Biblioteka „Spektar“, 1984). Такође, у првој половини XX века, када долази до наглог и учесталог интересовања наше културне средине за дела Висентеа Бласко Ибањеса, осим популарних романа овог аутора, на српски језик истовремено су превођене и његове одабране приповетке (од 20-их година XX века до данас укупно објављено је близу тридесет превода његових романа или збирки приповедака), а интересовање
} 
представља српском читаоцу све репрезентативне ауторе и одабране бисере шпанске кратке прозне форме, често у сенци великих шпанских романа. Критеријуми за одабир аутора и приповедака несумњиво су били значај и релевантност књижевног опуса у историји савременије шпанске књижевности. Такође, ангажовање искусних преводилаца и универзитетских професора, с једне, и младих и талентованих хиспаниста који чине прве професионалне кораке, с друге стране, сведоче о преко потребном тимском раду како би се локалној културној јавности у најбољем светлу и уз највише преводилачке стандарде, представио један овакав избор.

\section{3. Рецепција стваралаштва Бенита Перес Галдоса у академској средини}

Иако већ крајем XIX и у првој половини XX века у југословенској и српској културној и академској средини настају први преводи оригиналних шпанских књижевних дела, свест о потреби да се нашој публици приближе основе шпанске књижевне историје и књижевне критике биће тековина каснијих времена.У том смислу, од пресудног значаја је развој институционалног изучавања хиспанистике код нас, почев од шездесетих и седамдесетих година XX века. У оквиру тада југословенских универзитета постепено се уводи изучавање шпанског језика прво као помоћног, факултативног или изборног, а затим и као главног предмета (Филозофски факултет у Београду:

\footnotetext{
за кратку прозу Бласко Ибањеса не јењава ни у новије време (Visente Blasko Ibanjes. Poslednji lav. Izbor i prevod sa španskog Branislava Advigov, Vršac: Kov, Biblioteka „Atlas vetrova“, 2017). У протеклих двадесетак година објављени су избори савременијих шпанских и хиспаноамеричких прича (Nema više novih ljubavi - Savremena španska priča. Izabrao i priredio Srđa Sardelić, Beograd: Repro-graf, Biblioteka „Palabras“, 2003. / Љубавници, диносаури и утваре - Антологија хиспанске мини-приче. Приредио Фабијан Вике, превели са шпанског Маријана Ашанин, Душан Баралић, Ивана Веселиновић, Татјана Ђоровић, Лидија Лукић, Зорица Мандић, Светлана Милојевић, Александра Михајловић, Катарина Николић, Марија Пантић, Мирјана Секулић, Мерсиха Фејзовић, Самира Фејзовић, Крагујевац: ФИЛУМУС, 2007. / Digitalni život - hispanska priča novog milenijuma. Priredila i prevela Bojana Kovačević Petrović, Zrenjanin: Agora, 2017), али и преводи посебних антологија приповедака других шпанских писаца, махом припадника реализма друге половине XIX века, попут Леополда Алас Кларина (Leopoldo Alas Klarin. Pripovetke. Preveo sa španskog i pogovor napisao Vladimir Karanović, Pirot: Pi-Pres, Edicija „Klasici španskog realizma“, 2012) или Емилије Пардо Басан (Емилија Пардо Басан. Приче о љубави. Превела Снежана Вишњић, Београд: Репро-граф, 2013. / Emilija Pardo Basan. Božićne i novogodišnje priče. Prevela sa španskog Jovana Živanović, Beograd: Agnosta digital, 2017).
} 
1951; Филозофски факултет у Загребу: 1968; Филозофски факултет у Љубљани: 1981). Догађај од изузетне важности у развоју југословенске хиспанистике је оснивање Групе за шпански језик и књижевност на Филолошком факултету у Београду у оквиру студија романистике, 1971. године. Тако је након четворогодиших основних студија хиспанистике наша академска и културна средина коначно могла да рачуна на школоване хиспанисте, који ће кроз професионалну делатност и преношење знања наредним генерацијама створити повољну климу за развој оригиналне југословенске, а касније српске хиспанистичке монографске и научне активности. Током безмало 50 година постојања Групе за шпански језик и књижевност (данас Катедре за иберијске студије) на Филолошком факултету Универзитета у Београду, професори и предавачи су кроз свој академски рад и стручне активности настојали да домаћој јавности понуде већи број научних монографских издања у којима се разматрају различите теме савремене хиспанистике: рецепција шпанске и хиспаноамеричке књижевности на српском говорном подручју, нови хиспаноамерички роман, стваралаштво Мигела де Сервантеса, књижевност шпанског реализма, прагматика, фразеологија, контрастивна анализа шпанског и српског језика, сефардске студије, методика наставе шпанског језика, основи хиспанистике, хиспанска социолингвистика, компаративна истраживања шпанске и српске књижевности, итд.

Када је посреди књижевност шпанског реализма и, конкретно, стваралаштво и присуство Бенита Перес Галдоса код нас, можемо издвојити неколико публикација. Први траг о његовом делу у критичком или књижевноисторијском кључу јесте подухват професорке Љиљане Павловић-Самуровић, утемељивача академске хиспанистике код нас, под насловом Избор текстова из књижевности шпанског језика XIX-ог и ХХ-ог века (три издања: 1965, 1972,1981 . године). Књига је јасно конципирана као универзитетски приручник, намењен студентима у виду корпуса за изучавање и учење шпанског језика традуктолошком методом. Међу текстовима најважнијих шпанских и хиспаноамеричких писаца XIX и XX века, одељак посвећен Бениту Перес Галдосу (рр. 22-28) садржи кратку биографску напомену о писцу и основним одликама његових дела. Ауторка настоји да пружи основну информацију која студентима и другим заинтересованим читаоцима може послужити као основа за лакше савладавање контекста писца и његовог тада код нас мало познатог књижевног опуса. Након уводних података приложена су 
два оригинална одломка на шпанском језику из истоимених Перес Галдосових романа из серије „Епизоде националне историје“, под насловом Трафалгар и Сарагоса.

Први општи преглед историје шпанске књижевности на српском језику представља превод с енглеског оригиналног дела Џералда Бренана Шпанска књижевност, објављеног 1970. године у оквиру чувене едиције „Књижевност и цивилизација“ издавачке куће „Нолит“ из Београда. У поглављу под насловом „Проза деветнаестог века“ (рр. 344-378), Бренан разматра и стваралаштво Бенита Перес Галдоса, посветивши чак двадесетак страница опусу овог шпанског приповедача. Свестан значаја Перес Галдосовог књижевног дела, Бренан му указује велико поштовање и осуђује неправедан заборав и непостојање рецепције његовог стваралаштва ван граница Шпаније, премда по квалитету оно не заостају за делима великих европских реалиста, попут Балзака, Дикенса или Толстоја. Аутор представља биографске податке о писцу, посебно се осврћући на одабране мањепознате епизоде из свакодневног живота писца: његов друштвени живот, начин рада, комуникацију с колегама, културне активности и живот у престоници, итд. Врло темељно Бренан анализира радњу и ликове најважнијих романа разних фаза стваралаштва Перес Галдоса. Посебно су драгоцене оцене дела у контексту свеукупног романескног опуса. Последњи пасуси текста доносе једну објективну и уравнотежену оцену прозног опуса Перес Галдоса, и сведоче не само о Џералду Бренану као обавештеном историчару књижевности, већ и о књижевном критичару који при судовима узима у обзир конкретно дело али и знатно шири контекст, тј. значај дела у развоју шпанске националне књижевности.

Ова историја шпанске књижевности, преведена на српски језик у годинама повоја академског изучавања хиспанистике на нашим просторима, била је неретко предмет критике неких од пионира српске хиспанистике, а споран је највероватније био критеријум који Бренан примењује у одабиру књижевне грађе. Наиме, сматрао је да на селекцију материјала треба примењивати географски, тј. територијални критеријум, давно превазиђен и одбачен у савременијим прегледима историје шпанске књижевности, те је књигом обухваћена књижевност давних времена, настала на другим језицима, попут латинског, арапског, итд. Међутим, већ деценијама је у хиспанистици доминантан тзв. језички критеријум, по којем шпанској књижевности припадају дела написана на шпанском језику, од првих фаза његовог развоја до савременог 
лингвистичког израза, и то на тлу Иберијског полуострва (како би се шпанска књижевност дистанцирала од оне настале на шпанском језику у земљама Хиспанске Америке). Упркос овим, али и другим мањкавостима (спорна транскрипција имена са шпанског, понекад упитна фактографија, личан приступ аутора анализи књижевног корпуса, субјективни коментари и оцене), овај преглед историје шпанске књижевности несумњиво је био, и до дана данашњег остао, једна од најкомплетнијих општих публикација о шпанској књижевној историји на српском језику. Чини се да је ваљану оцену целокупног дела дао Хуан Октавио Пренс, аутор „Предговора“ (рр. 9-14) српском издању:

Ово дело попуњава приличну празнину у време када у Југославији расте интересовање за једну књижевност на европском тлу која се одликује веома оригиналним особинама. Књига Џералда Бренана потпуно је на висини озбиљних захтева читалаца. Она ће студенту или љубитељу пружити општи преглед који подстиче на даље продирање у занимљиву шпанску књижевност. А то је, управо, оно што Бренан и жели да постигне својим делом.

Шездесете и седамдесете године XX века у заједничком, југословенском културном простору, биле су тзв. „златне године“ издаваштва, време када су велики државни издавачи посвећено радили на приређивању квалитетних издања и озбиљних подухвата у многим областима културе и науке. Допринос овом визионарском културном процесу дао је и Никола Милићевић, кроатиста, професор савремене књижевности на Филозофском факултету у Загребу, преводилац са шпанског, француског, италијанског, португалског, латинског и неколико словенских језика, који је 1974. године у оквиру издавачке куће „Младост“ из Загреба објавио одељак под насловом „Шпањолска књижевност“, у чувеној вишетомној публикацији Повијест свјетске књижевности (Том 4). У одељку под насловом „Деветнаесто стољеће“ (рр. 284-300) Милићевић посвећује неколико страница стваралаштву Бенита Перес Галдоса, истичући пре свега значај овог писца у развоју шпанске књижевности реализма, који се истиче обимом и квалитетом свога дела. Читалац проналази основне податке о делу писца, класификованом по циклусима и тематским оквирима: од раних романа с тезом, преко романа о националној историји, до дела тзв. „духовног реализма“ из последњих година XIX века. Перес Галдос је представљен као прави реалиста, заинтересован да кроз романе понуди једну анатомску 
и комплетну анализу шпанског друштва онога времена, уз све његове мане, врлине и специфичности, непрестано водећи рачуна да се информације прикупе „на извору“, међу људима, пре свега на мадридским улицама, у кафеима, салонима, уз обавезну дозу друштвено-историјске анализе или тумачења спорних феномена шпанске духовности. У анализи и вредновању романа овог шпанског писца Милићевић повремено показује одлике строгог књижевног историчара и критичара, оцењујући нпр. да брзина рада и број објављених дела нису Галдосу омогућили уједначен квалитет нити погодно место свих дела у историји шпанске прозе. Осим тога, примећује да је радња неких дела недовољно развијена, ликови произвољни или неубедљиви, дела личе на скице или илуструју пуке идеје и идеологију без неких дубљих интелектуалних увида или књижевних квалитета. Ипак, Милићевић на крају износи тачну и врло важну оцену укупног књижевног дела Перес Галдоса, истичући да њена вредност не почива на квалитету појединачних дела, већ на комплетности, сложености и специфичности опуса који се искључиво посматра као целина.

Српски хиспанисти се у каснијим деценијама нису бавили шпанском књижевношћу реализма нити је предмет истраживања у академској средини било стваралаштво савременијих шпанских књижевника. У том смислу, повратак овом сегменту изучавања у оквирима српске хиспанистике представља монографска публикација Владимира Карановића - Шпанска књижевност реализма (2018), која садржи и обимније поглавље посвећено стваралаштву Бенита Перес Галдоса (рp. 158-217). По речима Далибора Солдатића (2019: 269), једног од рецензената, ова књига очигледан је резултат вишегодишњег истраживања и темељног рада аутора, посвећеног теми реализма и натурализма у шпанској књижевности, а циљ је био да се темељно изуче друштвеноисторијске околности, теоријски видови реализма, стваралаштво најважнијих књижевника ове кључне епохе у развоју шпанске књижевности. Солдатић истиче и да ова публикација попуњава велику празнину у корпусу монографија на српском језику које се баве разним видовима и епохама шпанске књижевности, јер је прва свеобухватна и темељна студија о свим репрезентативним појавама у шпанској књижевности наведене епохе, од изузетне важности за могуће компаративне студије у нашој културној и академској средини. Поглавље 8, о стваралаштву Бенита Перес Галдоса, представља исцрпну студију о разним видовима дела чувеног 
шпанског реалисте, једног од ретких у чијем опусу проналазимо интересовање за историјске, друштвене, колективне теме, с једне, али и за појединца и његове унутрашње светове, с друге стране. Осим биографских података, класификације књижевног стваралаштва, у поглављу су анализирани најрепрезентативнији Перес Галдосови романи у хронолошком следу. На крају аутор монографије књижевни опус шпанског реалисте квалификује као симболички мост који спаја све познате тенденције XIX века и најављује нове књижевне естетике које ће бити актуелне током XX века (Солдатић 2019: 271).

Након неколико деценија преводне и књижевноисторијске рецепције стваралаштва Бенита Перес Галдоса, у нашој академској средини јавља се и потреба да се различити видови његовог дела анализирају или преиспитају у светлу бројних савремених књижевних теорија и приступа књижевности. У том смислу велики допринос дали су српски хиспанисти посвећени изучавању пре свега шпанске књижевности XIX и XX века. Први научни чланак о неком виду дела Перес Галдоса објавила је Јелица Вељовић 2014. године у Зборнику радова са V научног скупа младих филолога Србије (Савремена проучавањајезика и књижевности), Година V, Књига 2, под насловом „Дијалектичко истражно осветљавање Шпаније 19. века у Перес Галдосовом роману Доња Перфекта“. Вељовић (2014: 693700) у чланку настоји да у кључу постструктуралистичке анализе дискурса представи идеолошку расправу у роману Доња Перфекта. Полазећи од концепције паноптикона, описане у текстовима Мишела Фукоа, ауторка детаљно разматра све важне епизоде романа у којима постоји симболичка комуникација између истражитеља и предмета истраге, тј. традиционализма и либерализма, као основе овог дела. Указује се на присуство свих истражних метода, на ток истражног процеса, посматрање, прикупљање информација, контролу простора, на основу којих супарничка идеологија бива осуђена. Вељовић примећује да услед оваквог приступа романескној радњи и структури дела Перес Галдос постаје нека врста врховног иследника целокупног шпанског друштва друге половине XIX века, а уједно и заговорник једне либералне и алтернативне идеологије која би могла допринети да се Шпанија, након векова догматизма, верског фанатизма и укорењеног традиционализма, коначно окрене савременим токовима и слободнијем начину живота.

Током 2017. године објављена су два чланка Владимира Карановића о различитим видовима анализе романескног корпуса Бенита Перес Галдоса. Чланак под насловом „Хронотопска стварност 
у роману Доња Перфекта Бенита Переса Галдоса“, објављен у часопису Филолошки преглед (2017/1, рр. 103-118), представља студију о хронотопској стварности и међуодносима просторних и временских координата у фиктивном амбијенту романа Доња Перфекта.У раду је анализирана мрежа хронотопа, али се наглашава и присуство антиидиличног хронотопа најопштијег типа, који је неретко пристуан у регионалистичком роману епохе. Хронотопска стварност и хронотопски след у делу у тесној су вези с идеолошким хоризонтима писца и у функцији тезе романа, коју Перес Галдос представља кроз амбијент, иронију, поларизацију ликова и непрестану борбу „две Шпаније“. Хронотопско одређење структуре овог романа, осим мреже просторних и временских преплитања и актуализација, свакако подразумева и општу околину у којој живе романескни ликови, пре свега њихове верске, моралне, духовне, социјалне и емоционалне околности живота. Карановић закључује да је Доња Перфекта један од шпанских реалистичких романа који најуспешније представља сукоб старог и новог, тј. две непомирљиве Шпаније, те да иако Перес Галдос заузима јасан либералан став према друштвеној организацији, бранећи право на личну слободу и право на избор, није могао да прихвати једнодимензионалну визију шпанске стварности и провинцијске свакодневице. Други рад истог аутора под насловом „Бенито Перес Галдос и «женско питање»: изгубљена слобода у роману Тристана“, објављен је у часопису Филолог (VIII 2017/16, pp. 195-210) Филолошког факултета Универзитета у Бањој Луци. У чланку су анализиране основне (анти)феминистичке поставке Бенита Перес Галдоса у контексту романа Тристана, насталог у кључном тренутку шпанске друштвене историје друге половине XIX века у којем тзв. „женско питање" има све већи значај. У анализи се полази од књижевног текста као друштвено-симболичког акта, носиоца идентитета и мреже текстуалних пукотина кроз које романописац комуницира с читаоцима у процесу актуализације књижевног дела. Предмет анализе је сплет идеолошких поставки романописца, који књижевни текст употребљава као средство за представљање конкретне идеолошке концепције, исказане кроз делање главних ликова, односе међу половима, али и манифестацију контроле и моћи у оквирима ригидног, традиционалистичког и андроцентричког буржоаског уређења. Основни проблеми обухваћени овим истраживањем јесу: одређивање елемената друштвене субверзије који припремају идеолошку подлогу за могућа освајања женске слободе, права на 
избор и формирање концепције „нове жене“; указивање на процес у којем се женско тело појављује као елемент идентитета и перцепције сопства; и, коначно, посматрање овог значајног романа као дела које представља савршену анализу (не)могућности које жена епохе има на располагању уколико жели да промени постојећи поредак и(ли) оствари личну слободу.

До сада последњи осврт на стваралаштво опуса Бенита Перес Галдоса дала је Снежана Јовановић 2018. године, објавивши чланак под насловом «La imagen de la mujer virtuosa y su intencionalidad en la novela La fontana de oro de Benito Pérez Galdós» у часопису Лиnap (XIX/67, pp. 191-200) Универзитета у Крагујевцу. Ова студија, по речима ауторке, није комплетна и нужно свеобухватна анализа теме, већ нека врста нацрта и приближавања концепцији жене и женске природе у роману Златна фонтана Перес Галдоса. У уводном делу текста представљене су друштвено-историјске околности, важни морални и религијски видови оновременог шпанског друштва, али и контекст развоја стваралаштва чувеног шпанског реалисте, неоспорно делимично инспирисаног некадашњим романима у наставцима чија је популарност била општепозната. У средишту анализе овог рада је лик Кларе, који сједињује све стереотипе андроцентричног погледа на идеал жене и на женску природу, што је ауторки послужило да илуструје идеолошку концепцију коју је заступао писац с Канарских острва.

У хиспанистичкој академској средини тек у последњим годинама се јављају први радови студената мастер студија који на српским универзитетима пажњу посвећују разним видовима анализе књижевног корпуса Бенита Перес Галдоса. Први рад који делимично обрађује дело шпанског реалисте под насловом „Реализам и натурализам у романима Регенткиња Леополда Алас Кларина и Разбаштињена Бенита Перес Галдоса", 2016. године одбранила је Данијела Казаковић на Филолошком факултету Универзитета у Београду, под менторством др Владимира Карановића. У овом раду анализирани су елементи књижевности реализма и натурализма, доминантни међу књижевницима и другим уметницима у шпанској књижевној и културној средини друге половине XIX века. Предмет анализе су утицаји ових праваца на њихова два највећа представника, Леополда Алас Кларина и Бенита Перес Галдоса. Представљени су критички текстови два аутора о поменутим правцима, о политици, критици друштва и цркве која је незаобилазна тема њихових дела. Истраживачки корпус су и два романа, Регенткиња Леополда Алас 
Кларина, и Разбаштињена Бенита Перес Галдоса, који омогућавају увиду главне одлике шпанског реализма и натурализма и повезивање теоријских ставова два писца с њиховом књижевном праксом.

На Филолошко-уметничком факултету Универзитета у Крагујевцу Јелена Стојановић одбранила је 2018. године мастер рад под насловом „Идиоматске конструкције у преводима Бенита Переса Галдоса на српски језик“, под менторством др Анете Тривић. У овом раду анализирају се преводи фразема у роману Разбаштињена. Циљ рада је тумачење преводилачких техника у преводу фразема који су разврстани по нивоима преводилачких еквиваленција. У првом делу рада представљен је теоријско-методолошки оквир у ком су дефинисани појмови „фразеологија“, „фразеолошка јединица“, представљена њихова класификација, технике и еквиваленције у процесу превођења, као и одлике фразема. Други део рада бави се анализом и тумачењем поменутих техника. Резултати анализе показују да у апсолутној еквиваленцији нема великих промена у преводу и оне не ремете значење фразема. Најчешће разлике су граматичка категорија, ред речи, различита употреба предлога, а неки фраземи у делимичној еквиваленцији су преведени слободно јер постоје делови у овим конструкцијама који се не поклапају у циљном језику.

У хронолошком следу најновији мастер рад у нашој академској средини је рад Јелене Пакљанац под насловом „Типолошка анализа женских ликова у романима Разбаштињена, Госпођа Брингас $u$ Фортуната и Хасинта Бенита Перес Галдоса“, одбрањен 2019. године на Филолошком факултету Универзитета у Београду (ментор проф. др Владимир Карановић). Ауторка у уводним поглављима објашњава контекст настанка и развоја дела овог шпанског писца, истичући значај буржоаске класе у Шпанији епохе. Ауторка примећује да је у романима Бенито Перес Галдос верно приказивао друштво епохе кроз ликове и догађаје, а највише пажње посвећивао је жени која је била у подређеном положају и лишена основних права. Преко женских ликова, честих протагониста романа, исказивао је жељу за друштвеном реформом и указивао на поремећени систем вредности. У овом истраживачком раду анализирани су женски ликови у романима Разбаштињена, Госпођа Брингас и Фортуната и Хасинта, с циљем да се утврди специфична улога жена у друштву, али и начин на који су представљене у одабраним романима и у којој мери су се уклапале у тадашње каноне понашања. На основу спроведене анализе закључује се да Перес Галдос ствара прототип жене који се, 
без обзира на прогресивно дистанцирање од буржоаског модела, и даље формира на основу патријархалног система.

\section{4. Закључак}

Осврт на присуство стваралаштва Бенита Перес Галдоса у нашој преводној, културној и академској средини потврђује претпоставку да је посреди двоструки вид рецепције: 1) пересгалдосовско стваралаштво се перципира, преводи и критички проматра кроз активности махом хиспаниста, након зачетака хиспанских студија на универзитетском нивоу у некада југословенском, а касније српском културном и академском амбијенту; 2) дело Перес Галдоса проучава се, анализира, преиспитује у академској, филолошкој и научној средини, чији подстицај су представљали први преводи или пак свест аутораิ о значају одређених романа овог шпанског реалисте у историји шпанске књижевности реализма и савременог прозног израза.

Рецепција овог де́ла корпуса шпанске књижевности реализма уклапа се у постојеће опште читалачке хоризонте очекивања код нас, те не успевамо да пронађемо трагове нпр. о конкретној књижевној рецепцији и опипљивим утицајима стваралаштва Бенита Перес Галдоса на наше писце. Разлоге за скромну рецепцију и симболичан утицај превода његових дела ван хиспанистичких кругова можда би требало потражити у неоспорној доминацији фосилизоване рецепције стваралаштва искључиво оних шпанских писаца који су на нашим просторима присутни захваљујући истовремено директном интеркултурном дијалогу шпанске и српске средине, али и индиректним, посредним путевима рецепције, кроз контакте српске средине и преводних књижевности других земаља.

Стваралаштво Бенита Перес Галдоса кроз преводну рецепцију присутно је у југословенској, а касније и српској културној средини још од средине XX века, када је на хрватскосрпску варијанту језика преведен роман Доња Перфекта. За разлику од пионирских превода дела других шпанских писаца епохе реализма, чија су дела у прво време превођена с француског језика, те посредно постајала део домаће преводне књижевности, удаљена од оригиналног шпанског текста као врста секундарне преводне рецепције, већ први, а и каснији преводи романа Бенита Перес Галдоса превођени су директно са шпанских оригиналних изворника. Одабир преведених дела је репрезентативан и српском читаоцу представља релевантан узорак разних етапа стваралаштва шпанског реалисте. У том смислу 
важан је и труд, али и преводилачки таленат који су хиспанисти показали у контакту с оригиналним шпанским изворницима, неретко захтевним и специфичним текстовима, који садрже бројне преводилачке изазове и за настанак ваљаног превода подразумевају изузетно преводилачко умеће.

Кључну улогу у порасту интересовања за дело овог шпанског писца имао је развој институционалног изучавања хиспанистике на овим просторима, а пре свега формирање Групе за шпански језик и књижевност на Филолошком факултету Универзитета у Београду, 1971. године. Преводна, књижевноисторијска и критичка рецепција дела Перес Галдоса неретко је била резултат личне иницијативе, у први мах образованих културних посленика ширег спектра интересовања и образовања, који су били заинтересовани за хиспанске теме, а потом и школованих хиспаниста и преводилаца, пре свега на српском културном простору, који су понудили превод најважнијих дела овог писца и прегршт пропратних критичких текстова који су могли утицати на хоризонт очекивања домаћег читаоца. Књижевнокритичка и књижевноисторијска активност јављају се некад паралелно, а често након објављивања превода дела, као одјек и последица критичког и теоријског уопштавања за које су потребни време и предан стручни и научни рад. Осим информативне функције, текстови наших хиспаниста (предговори, поговори, поглавља у монографским публикацијама, итд.) сведоче о високом степену свести о значају реализованог подухвата у дијалогу међу удаљеним културама. У пропратним текстовима није доминантан само информативни елемент како би се најшири круг читалаца обавестио о основама стваралаштва Бенита Перес Галдоса и разним видовима одабраних преведених дела, већ је циљ очигледно био, посебно у текстовима насталим у последњој деценији, да се хиспанисти и сви други „идеални читаоци“ у српској средини заинтересују за ову област и својим систематским радом и активностима допринесу развоју озбиљнијих студија књижевног опуса једног од најталентованијих и најплоднијих приповедача у историји шпанске књижевности. 


\section{ИЗВОРИ}

\section{Преводи:}

Перес Галдос 1952: Benito Pérez Galdós. Doña Perfecta. Sa španjolskog preveo Ivan Večerina. Napomena o piscu Milena Večerina, Zagreb: Državno izdavačko poduzeće Hrvatske, Mala biblioteka, 136.

Перес Галдос 2006: Benito Peres Galdos. Nazaren. Prevela Aleksandra Mančić, Beograd: Izdavačko preduzeće „Rad“, Biblioteka „Reč i misao", Knjiga 572.

Перес Галдос 2007a: Benito Peres Galdos. Doña Perfekta. Prevela sa španskog Biljana Bukvić, Beograd: Clio, Biblioteka „Gral“.

Перес Галдос 2007б: Benito Peres Galdos. Tristana. Prevela Aleksandra Mančić, Beograd: Izdavačko preduzeće „Rad“, Biblioteka „Reč i misao", Knjiga 583.

Перес Галдос 2008: Бенито Перес Галдос. Трафалгар. Са шпанског превео Владимир Нинковић, Београд: Утопија.

Перес Галдос 2012: Benito Peres Galdos. Razbaštinjena. Sa španskog preveo i pogovor napisao Dalibor Soldatić, Pirot: Pi-press, Edicija „Klasici španskog realizma“.

Перес Галдос 2014: Бенито Перез Галдос. „Донжуан“, превела Сара Јокић. Шпанска прича на прелазу из ХІХ У XX век. Избор текстова: Слободанка Стојановић, Ивана Катић, Драгана Бајић. Увод, биографске белешке и редакција текстова: Драгана Бајић. Уредник: Милош Константиновић. Преводиоци: Исидора Грађанин, Ања Животић, Марија Јанковић, Сара Јокић, Милица Крстић, Јелена Младеновић, Тања Младеновић, Наталија Новоградски, Растко Петровић, Милица Тасић, Биљана Тодоровић, Ана Хубер, Београд: Мостови, часопис УКПС, 87-93.

Перес Галдос 2015: Benito Peres Galdos. Fortunata i Hasinta (Dve priče o udatim ženama), 2 toma. Prevod sa španskog, pogovor i napomene Dalibor Soldatić, Beograd: Partenon, Bibliotheca Hispania.

Перес Галдос 2018: Benito Peres Galdos. Zlatna fontana. Prevod sa španskog, beleške i pogovor Snežana Jovanović, Beograd: Partenon, Bibliotheca Hispania.

Перес Галдос 2019: Benito Peres Galdos. „Slagalica ili glavolom“, „Gde mi je glava?", prevela Dragana Bajić. Slagalica - Antologija španske priče XX veka, Tom 1. Priredila Dragana Bajić. Preveli Dragana Bajić, Anđela Delić, Srđa Sardelić, Dalibor Soldatić, Anđela Gašić, Jelena Rajić, Jasna Stojanović, Bojana Kovačević Petrović, Ljubica Trošić, 
Ivana Nikolić. Redaktor prevoda Dragana Bajić, Zrenjanin: Agora, Biblioteka „Pogled preko svega“, Knjiga 15, 10-18.

\section{Научни чланци, стручни текстови и мастер радови:}

Бајић 2014: Драгана Бајић. „Кратка уводна реч за кратку антологију“. Шпанска прича на прелазу из XIX у XX век. Избор текстова: Слободанка Стојановић, Ивана Катић, Драгана Бајић. Увод, биографске белешке и редакција текстова: Драгана Бајић. Уредник: Милош Константиновић. Преводиоци: Исидора Грађанин, Ања Животић, Марија Јанковић, Сара Јокић, Милица Крстић, Јелена Младеновић, Тања Младеновић, Наталија Новоградски, Растко Петровић, Милица Тасић, Биљана Тодоровић, Ана Хубер, Београд: Мостови, часопис УКПС, 9-11.

Бајић 2019: Dragana Bajić. „Predgovor“. Slagalica - Antologija španske priče XX veka, Tom 1. Priredila Dragana Bajić. Preveli Dragana Bajić Anđela Delić, Srđa Sardelić, Dalibor Soldatić, Anđela Gašić, Jelena Rajić, Jasna Stojanović, Bojana Kovačević Petrović, Ljubica Trošić, Ivana Nikolić. Redaktor prevoda Dragana Bajić, Zrenjanin: Agora, Biblioteka „Pogled preko svega“, Knjiga 15, 5-8.

Вељовић 2014: Јелица Вељовић. „Дијалектичко истражно осветљавање Шпаније 19. века у Перес Галдосовом роману Доња Перфекта“. Маја Анђелковић (уредница), Савремена проучавања језика и књижевности (Зборник радова са V научног скупа младих филолога Србије, одржаног 30. марта 2013. године на Филолошко-уметничком факултету у Крагујевцу), Година V, Књига 2, 693-700.

Вечерина 1952: Milena Večerina. „Napomena o piscu“. Benito Pérez Galdós. Doña Perfecta. Sa španjolskog preveo Ivan Večerina. Napomena o piscu Milena Večerina, Zagreb: Državno izdavačko poduzeće Hrvatske, Mala biblioteka, 136, 241-244.

Јовановић 2018a: Snežana Jovanović. „Benito Peres Galdos i roman španskog realizma“. Benito Peres Galdos. Zlatna fontana. Prevod sa španskog, beleške i pogovor Snežana Jovanović, Beograd: Partenon, Bibliotheca Hispania, 341-351.

Јовановић 2018б: Snežana Jovanović. «La imagen de la mujer virtuosa y su intencionalidad en la novela La fontana de oro de Benito Pérez Galdós». Lipar, časopis za književnost, jezik, umetnost i kulturu, Godina XIX, Vol. 67: 191-200. 
Казаковић 2016: Данијела Казаковић. „Реализам и натурализам у романима Регенткиња Леополда Алас Кларина и Разбаштињена Бенита Перес Галдоса", мастер рад одбрањен на Филолошком факултету Универзитета у Београду, ментор др Владимир Карановић.

Карановић 2017а: Владимир Карановић. „Бенито Перес Галдос и „женско питање“: изгубљена слобода у роману Тристана“. Филолог, часопис за језик, књижевност и културу, VIII, Vol. 16: 195-210.

Карановић 2017б: Владимир Карановић. „Хронотопска стварност у роману Доња Перфекта Бенита Переса Галдоса“. Филолошки преглед, часопис за страну филологију, XLIV, Vol. 1: 103-118.

Манчић 2006: Aleksandra Mančić. „O piscu i delu“. Benito Peres Galdos. Nazaren. Prevela Aleksandra Mančić, Beograd: Izdavačko preduzeće „Rad“, Biblioteka „Reč i misao“, Knjiga 572, 217-219.

Манчић 2007: Aleksandra Mančić. „Galdos u Bunjuelovoj biblioteci“. Benito Peres Galdos. Tristana. Prevela Aleksandra Mančić, Beograd: Izdavačko preduzeće „Rad“, Biblioteka „Reč i misao“, Knjiga 583, 197-202.

Нинковић 2008: Владимир Нинковић. „Белешка о писцу“. Бенито Перес Галдос. Трафалгар. Са шпанског превео Владимир Нинковић, Београд: Утопија, 157-158.

Пакљанац 2019: Јелена Пакљанац. „Типолошка анализа женских ликова у романима Разбаштињена, Госпођа Брингас $u$ Фортуната и Хасинта Бенита Перес Галдоса“, мастер рад одбрањен на Филолошком факултету Универзитета у Београду, ментор др Владимир Карановић.

Пренс 1970: Huan Oktavio Prens. „Predgovor“. Džerald Brenan, Španska književnost. Prevela Maristela Matulić-Veličković. Redakcija prevoda i prevod stihova Radoje Tatić. Predgovor Huan Oktavio Prens, Beograd: Nolit, „Književnost i civilizacija“, 9-14.

Солдатић 2015: Dalibor Soldatić. „Benito Peres Galdos i španski roman“. Benito Peres Galdos. Fortunata i Hasinta (Dve priče o udatim ženama), Tom 2. Prevod sa španskog, pogovor i napomene Dalibor Soldatić, Beograd: Partenon, Bibliotheca Hispania, 517-521.

Стојановић 2018: Јелена Стојановић. „Идиоматске конструкције у преводима Бенита Переса Галдоса на српски језик“, мастер рад одбрањен на Филолошко-уметничком факултету Универзитета у Крагујевцу, менторка др Анета Тривић. 


\section{Поглавља у монографским публикацијама:}

Бренан 1970: Džerald Brenan. „Proza devetnaestog veka“. Džerald Brenan, Španska književnost. Prevela Maristela Matulić-Veličković. Redakcija prevoda i prevod stihova Radoje Tatić. Predgovor Huan Oktavio Prens, Beograd: Nolit, „Književnost i civilizacija“, 344-378.

Карановић 2018: Vladimir Karanović. „Benito Peres Galdos“. Vladimir Karanović, Španska književnost realizma. Beograd: Filološki fakultet, 158-217.

Милићевић 1974: Nikola Milićević. „Španjolska književnost“. Frano Čale et al. (Urednici), Povijest svjetske književnosti, Knjiga 4, uredio Mate Zorić, Zagreb: Mladost (Izdavačko knjižarsko poduzeće), 209-336.

Павловић-Самуровић 1972: Ljiljana Pavlović-Samurović. „Benito Pérez Galdós“. Ljiljana Pavlović-Samurović, Izbor tekstova iz književnosti španskog jezika XIX-og i XX-og veka. Drugo, dopunjeno izdanje, Beograd: Naučna knjiga, Univerzitetski udžbenici, 22-28.

\section{БИБЛИОГРАФИЈА}

Буњак 1998: Петар Буњак. „О питању историје рецепције стране књижевности“, Књижевна историја, часопис за науку о књижевности, XXX/104: 5-26.

Дицков 2014: Vesna Dickov. «Las literaturas hispánicas y el pensamiento crítico y teórico serbio», Colindancias, 5: 75-102.

[https://colindancias.uvt.ro/index.php/colindancias/article/ view/41] Web. 15/11/2019.

Донић 2017: Željko Donić. Reseña: «La colección Bibliotheca Hispania en la casa editorial Partenon: primera colección de clásicos hispánicos», Beoiberística, revista de estudios ibéricos, latinoamericanos y comparativos, I/1: 205-210.

[http://beoiberistica.fil.bg.ac.rs/index.php/beoiberistica/article/ view/16/16] Web. 15/02/2020.

Јанићијевић 1977: Jovan Janićijević. „Prevodna književnost“, Kultura, 38 : 40-50.

Манчић 2010: Александра Манчић. Превод и критика. Београд: Институт за књижевност и уметност.

Солдатић 2010: Dalibor Soldatić. «Las literaturas hispánicas en Serbia», Colindancias, 1: 21-28, [https://colindancias.uvt.ro/index.php/ colindancias/article/view/99] Web. 24/07/2018. 
Солдатић 2019: Dalibor Soldatić. Reseña: «Vladimir Karanović. Španska književnost realizma, Beograd: Filološki fakultet, 2018. 474 pp.», Verba Hispanica, XXVII/1: 269-273.

\section{Интернет странице:}

Fond „Radoje Tatić“. „Obrazloženje žirija 2008“. Web. 13/02/2020. [http://www.forata.org/sr/fond/nagrada/119/Obrazlo\%C5\%BE enje-\%C5\%BEirija-2008.htm]

\section{THE RECEPTION OF BENITO PÉREZ GALDÓS'S LITERARY WORKS IN SERBIAN CULTURAL AND ACADEMIC ENVIRONMENT}

\section{Summary}

In the past decades, the reception and presence of Spanish literature in the Balkan Peninsula, and particularly in Serbia, have been the subject of interest and research of our distinguished Hispanics, who have studied its translation, but also literary-historical, critical, artistic and cultural reception. The first traces of the presence and reception of Benito Pérez Galdós's works are related to the middle of the $20^{\text {th }}$ century when the novel Doña Perfecta was translated into Croatian-Serbian. Not until the first decade of the $21^{\text {st }}$ century can we talk about systematic translation activity and more serious translation, critical, literaryhistorical and academic reception of the literary works of this significant Spanish storyteller.

This article aims to present the corpus of Benito Pérez Galdós's work translated into Serbian (from the mid-twentieth century to the present) and to analyze its reception through the translation and reading experience of translators and Hispanics in Serbia. Literary-critical, literary-historical, scientific and professional texts devoted to different forms and aspects of Pérez Galdós's works (introductions, epilogs, chapters in thematic volumes, scientific articles published in journals, master thesis papers defended at Serbian universities) are also the subjects of the research.

The translation, literary-historical and critical reception of Peres Galdos's work was often the result of a personal initiative, at first by educated cultural workers of a wide range of interests and education, who were interested in Hispanic topics, and then by educated Hispanics and translators, primarily in the Serbian cultural environment, who offered a translation of this writer's most important works and a handful of accompanying critical texts that may have influenced the horizon of expectation for the domestic reader. Literary-critical 
and literary-historical activity sometimes occur in parallel, and often after the publication of a translation of a work, as an echo and consequence of critical and theoretical generalization that require time and dedicated professional and scientific work. Except for the information function, the texts of our Hispanics testify about a high level of awareness when it comes to the importance of the work done in the process of dialogue between distant cultures.

Keywords: Reception of Spanish literature, Benito Pérez Galdós, Spanish Realist literature, literary translation, Hispanic Studies in Serbia. 